\title{
Вопросы сохранения исторической среды города-курорта Светлогорск (Калининградская область)
}

\author{
В.И.Пустовгаров, Калининград
}

Актуальность данной статьи обусловлена тем, что историческая среда в городах подвержена серьёзным изменениям ввиду возросшего интереса застройщиков к строительству в исторических зонах, использования исторического потенциала территорий для продвижения различных проектов, направленных прежде всего на многоэтажное жилищное строительство. Состояние исторической застройки городакурорта федерального значения Светлогорска Калининградской области вызывает определённые вопросы, в том числе связанные с сохранением объектов культурного наследия. Историческая городская среда Светлогорска в целом представляет значительную культурную ценность, при этом ресурс исторического наследия города - значительный, разностильный и многообразный - требует дальнейших исследований.

Основная часть архитектурных памятников, расположенных в городе, относится к выявленным объектам культурного наследия, но часть их реконструируется, разрушается, и на их месте или на прилегающих территориях из-за значительного спроса на объекты недвижимости в курортном городе возводятся многоэтажные жилые дома. В последние три года были проведены определённые работы по подготовке документов на перевод выявленных объектов культурного наследия в объекты культурного наследия регионального, местного значения, но этот процесс опять затягивается, и при этом возникают всё новые грандиозные проекты по застройке ценных исторических территорий. Мы совершенно забыли, например, что существует и иной вид выражения величия и силы, кроме грандиозного. Мастера прошлого это знали и создавали произведения подлинного искусства, говорящие языком истинного величия покоя и простоты... [1].

Ключевые слова: градостроительство, Светлогорск, историческая городская среда, объекты культурного наследия, памятники архитектуры.

Issues of Preserving the Historical Environment of the Resort City of Svetlogorsk

V.I. Pustovgarov, IKBFU, Kaliningrad

The relevance of the article is due to the fact that historical environment in the cities is subject to major changes due to increased interest of developers in construction in historical areas and the use of historical potential of the territories for promotion of various projects, primarily in multistory housing construction. The state of the historical development of the city of Svetlogorsk of the Kaliningrad region - a resort federal city
- raises certain issues, including those related to preservation of cultural heritage. The historical urban environment of Svetlogorsk is of significant cultural value, while the historical heritage resources of the city are numerous and diverse, which requires further research. The majority of architectural monuments are registered as identified cultural heritage sites, but some of them are being reconstructed or destroyed. Multistory residential buildings are being built in their place or adjacent territories due to significant demand for real estate in the resort city of Svetlogorsk. In the last three years, some work has been done to prepare documentation to transfer the identified cultural heritage sites to cultural heritage sites of regional and local significance, but this process is delayed once again, while new ambitious projects on the development of valuable historical territories arise. It seems important to remember that there are other means of expressing greatness and strength, apart from the grandeur. Masters of the past understood this and created true works of art that spoke the language of true greatness of peace and simplicity... [1].

Keywords: urban planning, Svetlogorsk, historic urban environment, objects of cultural heritage, monuments of architecture.

Светлогорск - город в Калининградской области, центр Светлогорского городского округа. Он прежде назывался Раушен, что означает «шум моря» и впервые был упомянут в 1258 году как прусское рыбацкое поселение Русемотер. Краевед и почётный гражданин города Фишхаузена (совр. Приморск, Калининградская область) Оскар Шлихт (0. Schlcht, 1867-1955) так описывает зарождение этой местности: «Раушен - это старопрусское поселение, упомянутое в 1258 году как Русемотер, также это название есть в завещании от 1458 года, по которому Альбрехт фон Равшен получал четыре гуфена (1 гуфен - около 17 га) в деревне Зассио (совр. улицы Балтийская и Заречная в Светлогорске). По преданию, ранее здесь был замок, как минимум старый крепостной вал, в местности восточнее Кляйнтайхштрассе (Малая Прудная в Раушене; совр. улица Карла Маркса). На карте 1865 года крепостной вал ещё обозначен, а связанные с ним сказания ходили в народе до 1920-х годов. Старый Раушен был очень бедной деревней, заселённой рыбаками - пруссами и куршами, которые всё же оставались "свободными пруссаками"» [2]. После завоевания в XIII веке Самбийского (ныне Калининградский) полуострова Тевтонским орденом - поселение называлось Раушемотер. 
Первые отдыхающие появились в этой местности ещё в 1813 году и использовали для проживания домики рыбаков. Они останавливались в рыбацкой деревушке Раушен у пруда Мюллентайх (совр. озеро Тихое). Дата официального открытия курорта Раушена - 24 июля 1820 года [3]. Событием же, давшим реальный толчок к развитию Раушена как курорта нацонального значения, стало посещение его прусским королём Фридрихом-Вильгельмом IV, который был очарован красотой этих мест.

Интенсивное развитие курорта связано с открытием железнодорожного сообщения с Кёнигсбергом. Началось строительство лечебниц, пансионатов и частных вилл. Город условно разделился на две части: «нижний мир» - около пруда, «верхний мир» - у моря (рис. 1). В 1904 году был обустроен деревянный променад. Особенным украшением Раушена

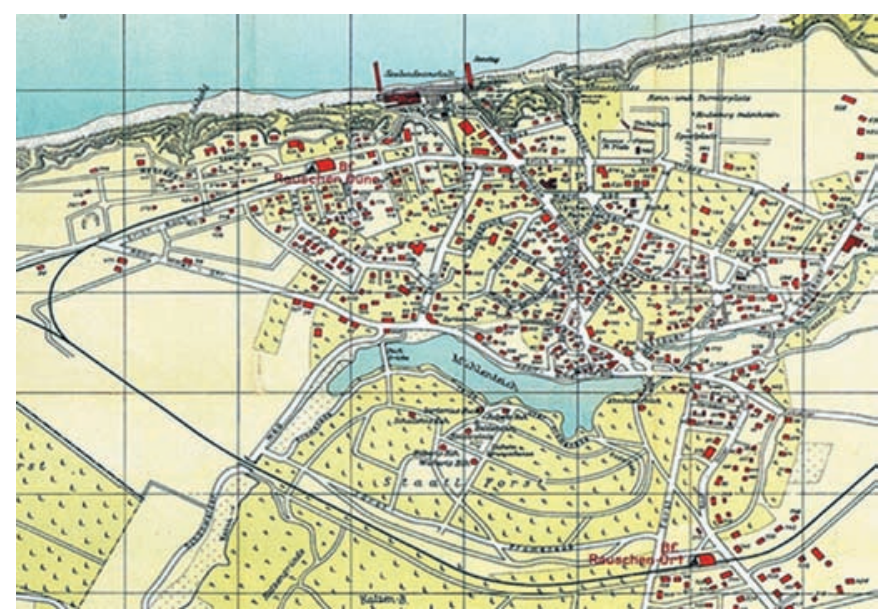

Pис. 1. План Раушена (Светлогорска). Фрагмент. 1936 год [источник: Берлин. Библиотека Прусского культурного наследия. Зал карт. Отдел Унтер ден Линден. № 10 439. План в целом сопровождается полным перечнем частных и общественных сооружений, с указанием их владельцев (всего 650 пронумерованных объектов). Опубликован под названием «PharusPlan Ostseebad Rauschen, 1941 // Königsberg und Ostpreußen in historischen Ansichten und Plänen. Berlin, 2007. S. 145. N. 139»]

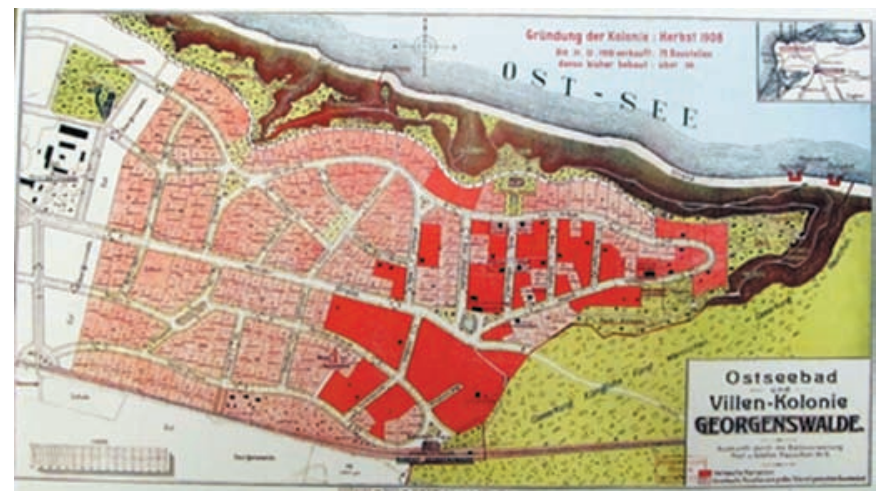

Рис. 2. План перспективного развития Георгенсвальде (Отрадное - современный район Светлогорска). 1910 год (источник: http://www.ostpreussen.net/ostpreussen/orte. php?bericht=1493) стала построенная в 1907-1908 годах грязеводолечебница с большим купольным залом и башней высотой 25 метров, ставшими частью возведённого по единому плану целого курортного комплекса, используемого по своему назначению и в настоящее время. Автор проекта - 0тто-Вальтер Куккук.

Известный скульптор Герман Брахерт украсил парки и променад своими произведениями, которые очень органично вписывались в природные и рукотворные ландшафты.

В границах города Светлогорска расположен посёлок Отрадное (Георгенсвальде), который появился гораздо позднее, чем Раушен. Большинство курортов Восточной Пруссии, находящихся на территории современной Калининградской области, возникали в начале XIX века на месте небольших рыбацких деревушек и развивались поначалу стихийно, без определённого плана. Посёлок Георгенсвальде, построенный спустя столетие по единому замыслу, интересен благодаря стилистическому единству элементов застройки начала XX века, сохранившихся до настоящего времени [4] (рис. 2).

Наряду с застройкой в городе-курорте возводились берегозащитные сооружения, которые являлись необходимыми элементами градостроительного освоения прибрежной территории. Для укрепления побережья применялась как естественная (природная), так и искусственная защита берегов.

В комплексе с гидротехническими сооружениями на побережье в периоды с 1911-го по 1914-й и с 1925-го по 1927-й годы в городе были проведены противооползневые, дренажные, агролесомелиоративные мероприятия, а также работы, направленные на урегулирование поверхностного стока.

В период военных действий (1945) во время Великой 0течественной войны город не пострадал.

В 1946 году Раушен был переименован в Светлогорск.

Период с 1945 года по настоящее время можно разделить на два качественно различающихся этапа развития: советский (в условиях административно-командной системы) 1945-1991 годы, и постсоветский - с 1992 года по настоящее время [5].

В 1971 году светлогорские здравницы получили статус республиканских курортов, а 29 марта 1999 года постановлением Правительства РФ Светлогорску присвоен статус курорта федерального значения.

На территории города сохранились постройки XIX - начала XX века в виде вилл, жилых домов и общественных зданий. При их возведении рационально использовались достоинства пересечённой местности, что привело к появлению оригинальных по архитектуре строений.

В советский период одним из первых градостроительных документов, разработанных для территории Калининградской области, был проект планировки города Светлогорска, выполненный институтом «Ленгипрогор» в 1961 году, в котором полностью сохранялась довоенная планировочная структура. Следует привести выдержки из данного проекта: «Для курортной зоны определена территория между железной дорогой и морем от посёлка Лесное до посёлка Рыбное. В курортной зоне 
предлагается создание баз отдыха, которые включают дома отдыха, гостиницы, турбазы. Селитебная зона города создаётся южнее железной дороги, занимая наиболее благоприятные для новой застройки территории, примыкающие к лесопарку».

Застройка курортной зоны в настоящее время полностью противоречит решениям указанного проекта планировки. Можно отметить основные проблемы, связанные с сохранением исторической среды города-курорта федерального значения Светлогорска:

- отсутствие градостроительной документации, выполненной на основе научных историко-культурных исследований и анализа историко-градостроительного потенциала;

- попадание в зону риска исторической территории города, олицетворяющей её неповторимость, природно-ландшафтное, средовое своеобразие, уникальную архитектурнопланировочную организацию;

- застройка исторического центра многоэтажными жилыми домами без учёта объектов культурного наследия;

- недостаточное использование историко-культурного и природного потенциала для развития туристической отрасли.

На территории Светлогорска находится 79 объектов культурного наследия регионального, местного значения и выявленных объектов культурного наследия, при этом статус выявленных объектов культурного наследия имеет основная часть памятников архитектуры. Выявленными объектами культурного наследия они были определены ещё в 2008 году приказом Службы государственной охраны объектов культурного наследия Калининградской области, но в объекты культурного наследия регионального или местного значения они в большинстве своём так и не переведены, хотя необходимые исследования для включения их в государственный реестр объектов культурного наследия проводились и предложения по проектам границ территорий были разработаны. Механизм сохранения объектов культурного наследия установлен Федеральным законом от 25.06.2002 № 73-Ф3 «0б объектах культурного наследия (памятниках истории и культуры) народов Российской Федерации» ${ }^{1}$ и статьёй 34.1 Федерального закона от 05.04.2016 № 95-Ф3², в которых введены зоны охраны и защитные зоны.

То есть исторический центр Светлогорска, при наличии значительного количества памятников архитектуры мог бы быть сохранён практически с минимальными потерями, но из-за того, что более десяти лет выявленные объекты культурного наследия не переводятся в объекты культурного наследия, охранные нормы указанных законов не действуют в полном объёме.

В 2011 году был утверждён проект зон охраны объектов культурного наследия регионального значения. В этот один проект каким-то образом удалось включить почти все объекты культурного наследия регионального значения, находящиеся в Калининградской области, в том числе и шесть объектов, расположенных в центральной исторической части города Светлогорска. Выполнение такого масштабного проекта, к сожалению, было осуществлено без учёта нормативноправовых требований, необходимых научных исследований, и, как результат, - регламентирующая часть проекта носит формальный характер (рис. 3).

Поэтому в исторической зоне города продолжается строительство жилых домов, причём исключительно повышенной этажности, хотя исторический масштаб города - это малоэтажные здания. И, в итоге, мы наблюдаем немасштабную и дисгармоничную застройку исторических улиц: Октябрьской, Ленина, Динамо, Аптечной, Калининградского проспекта и др. (рис. 4, 5, 6).

При этом меняется градостроительная структура города. Так, например, после возведения торгового центра на центральной площади города значительно ухудшилась планировочная структура всей центральной исторической части города, исчезла система связанных друг с другом архитектурно оформленных городских пространств (рис. 7).

Следует отметить, что к объектам культурного наследия относятся также достопримечательные места - творения, созданные человеком, или совместные творения человека и природы, в том числе места традиционного бытования народных художественных промыслов; центры исторических поселений или фрагменты градостроительной планировки и застройки; памятные места, культурные и природные ландшафты, связанные с историей формирования народов и иных этнических общностей на территории Российской Федерации ${ }^{3}$.

В этой связи было бы целесообразно рассмотреть возможность придания историческому центру города Светлогорска статуса «достопримечательное место».

${ }^{1}$ Федеральный закон от 25.06.2002 № 73-Ф3 «0б объектах культурного наследия (памятниках истории и культуры) народов Российской Федерации». - М., 2005.

2 Федеральный закон от 05.04.2016 № 95-Ф3 «0 внесении изменений в Федеральный закон "0б объектах культурного наследия (памятниках истории и культуры) народов Российской Федерации"» и статья 15 Федерального закона «0 государственном кадастре недвижимости». - М., 2016.

${ }^{3}$ Градостроительный кодекс РФ от 29 декабря 2004 г. № 190-ФЗ. - М., 2005.

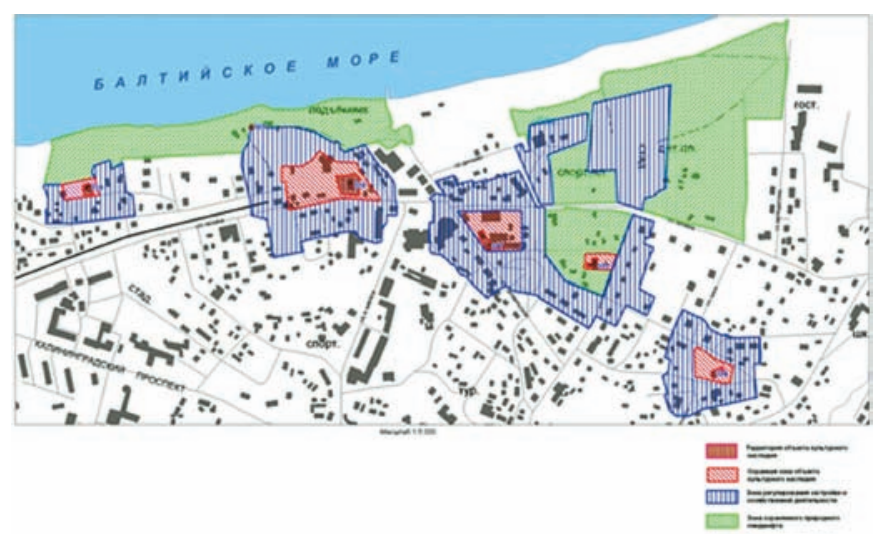

Рис. 3. Проект зон охраны объектов культурного наследия регионального значения в центральной исторической части города Светлогорска. 2011 год 
Пока же можно привести список тех выявленных объектов культурного наследия, которым требуются срочные меры по сохранению и реставрации:

- «Дом жилой» по улице Гагарина, 17 (рис. 8). Трёхэтажный многоквартирный жилой дом, который был построен в стиле модерн в начале XX века. Уже несколько лет здание не эксплуатируется;

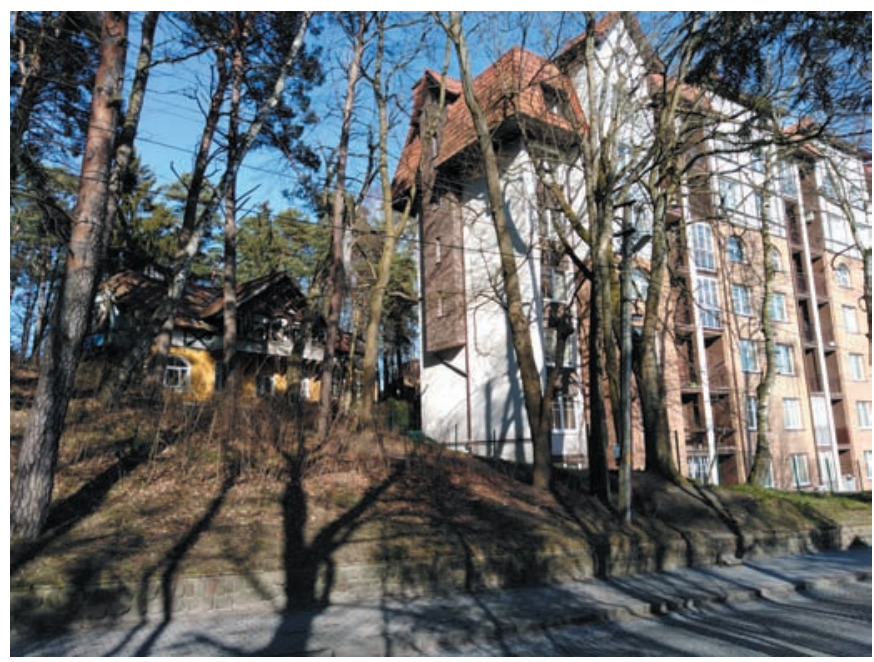

Pис. 4. Пример построенного многоэтажного жилого дома вблизи выявленного объекта культурного наследия «Вилла» (Калининградский проспект, 73). Фото В.И. Пустовгарова. $201920 \partial$

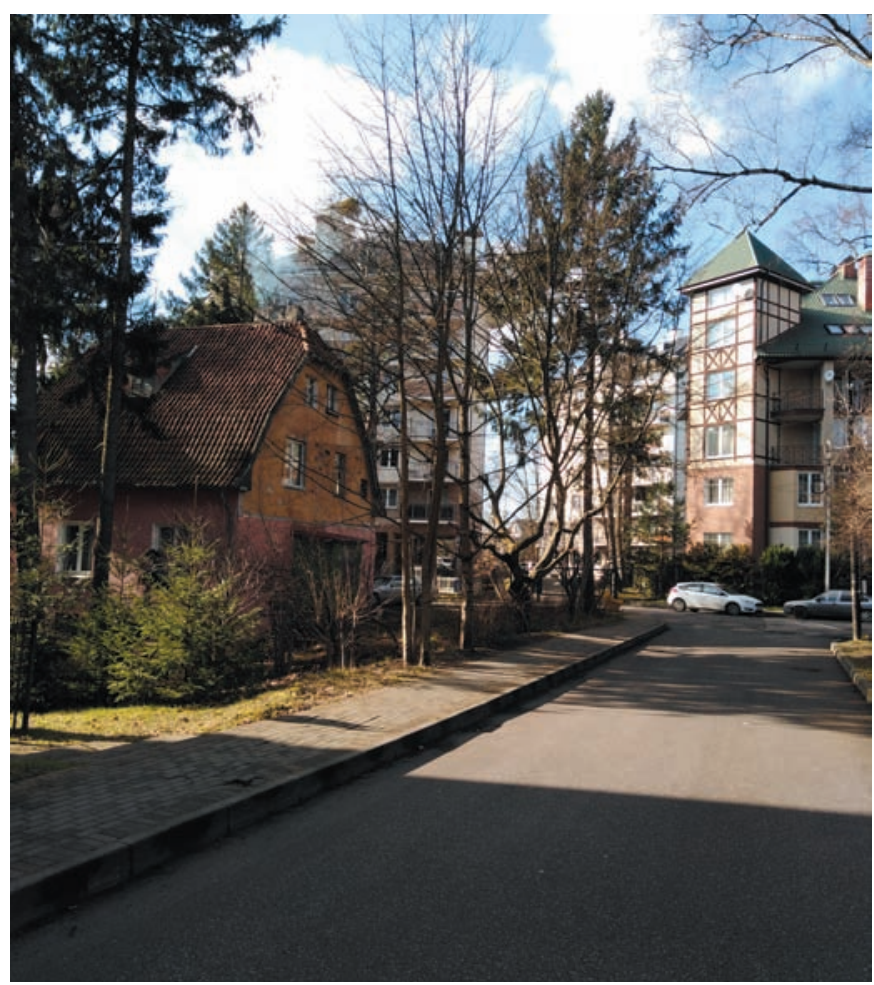

Pис. 5. Пример построенных многоэтажных жилых домов в исторической зоне в районе улицы Аптечной. Фото В.И. Пустовгарова. 2019 год
- «Дом жилой» по улице Октябрьская, 9;

- «Вилла» по улице Зелёной, 6 (рис. 9). Здание в стиле модерн построено в начале XX века как пансионат «Дюненхайм» («Дом на дюне»);

- «Вилла» по Заречному проезду, 5 (рис. 10). Двухэтажное здание в стиле неоклассицизм, построенное в начале XX века. В настоящее время происходит разрушение здания;

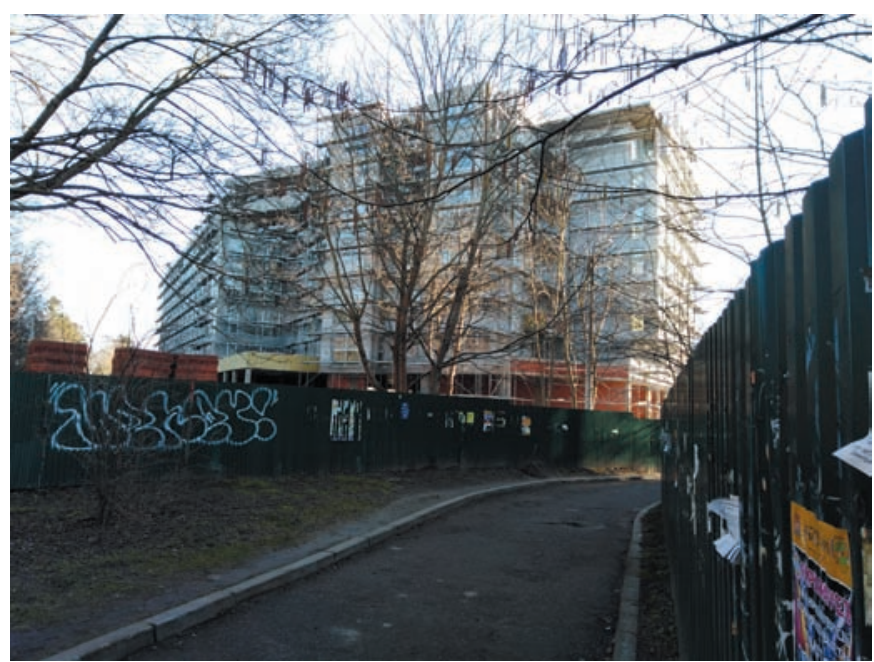

Pис. 6. Строящийся многоэтажный жилой дом на территории, прилегающей к Калининградскому проспекту. Фото В.И. Пустовгарова. 2020 год

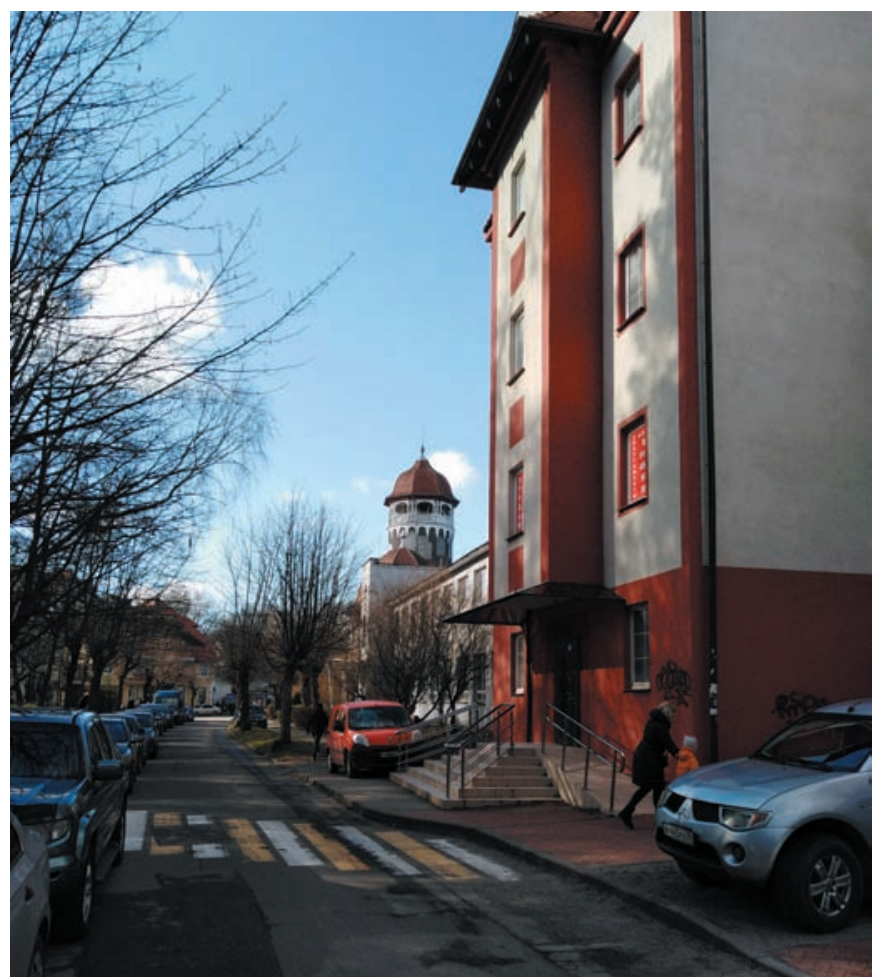

Рис. 7. Фрагмент торгового центра, построенного на бывшей центральной площади города. Фото В.И. Пустовгарова. 2019 год 
- «Вилла Розенхаус» по улице Гагарина, 6 (рис. 11). Жилое здание, которое возведено в типичном для Раушена начала $\mathrm{XX}$ века стиле модерн;

- «Дом жилой» по улице Пушкина 1;

- историческое здание по улице Московская, 1 (рис. 12). Уже несколько лет здание не эксплуатируется.

Применительно к градостроительному наследию на практике охрана означает создание необходимых условий для продолжения полноценного функционирования градостроительного «организма», приспособление его к существованию в современных условиях, но с тем условием, чтобы они не наносили ущерба его историческому облику.

Именно по этой причине среда Светлогорска представляет собой памятник градостроительного искусства, с утратой которого исчезает тот самый единственный и неповторимый город.

Важнейшими задачами работы с градостроительным наследием, отмечает А.С. Щенков в книге «Реконструкция исторических городов», является раскрытие и сохранение его общественной ценности и включение его в современную жизнь. Для решения обеих задач, прежде всего, необходимо ясно представлять, в чем состоит общественная ценность градостроительного наследия, что составляет предмет его охраны [6].

В пределах исторической зоны города предметами охраны могут являться:

- памятники архитектуры и градостроительства;

- сохранившаяся планировочная структура;

- сохранившаяся сеть улиц, площадей и озеленённых пространств;

- зоны визуальных раскрытий, композиционного влияния, композиционные узлы и акценты;

- территории возможных культурных слоёв.

Тема сохранения объектов культурного наследия неоднократно звучит на форумах по формированию комфортной среды проживания и развитию общественных пространств. Туристы, приезжающие в Калининградскую область, стараются увидеть памятники архитектуры, и во всех отчётах и презентациях о Янтарном крае демонстрируется облик наиболее ценных объектов культурного наследия.

В российском законодательстве памятники архитектуры в целом находятся под защитой, предусматривающей установление зон охраны для отдельных объектов культурного наследия, объединённых зон охраны, защитных зон, а также сохранение крупных фрагментов историко-градостроительной среды в виде достопримечательных мест, но эффективность механизмов сохранения этих объектов зависит в первую очередь от качества государственного контроля за соблюдением режимов, установленных для таких зон и территорий, от органов власти различных уровней, готовых эти требования соблюдать, и, конечно, от граждан.

Восприятие архитектурного пространства, то есть искусственно созданной среды для жизнедеятельности людей, не сводится к зрительной оценке формальной упорядоченности, а формируется во взаимосвязи с функциональными

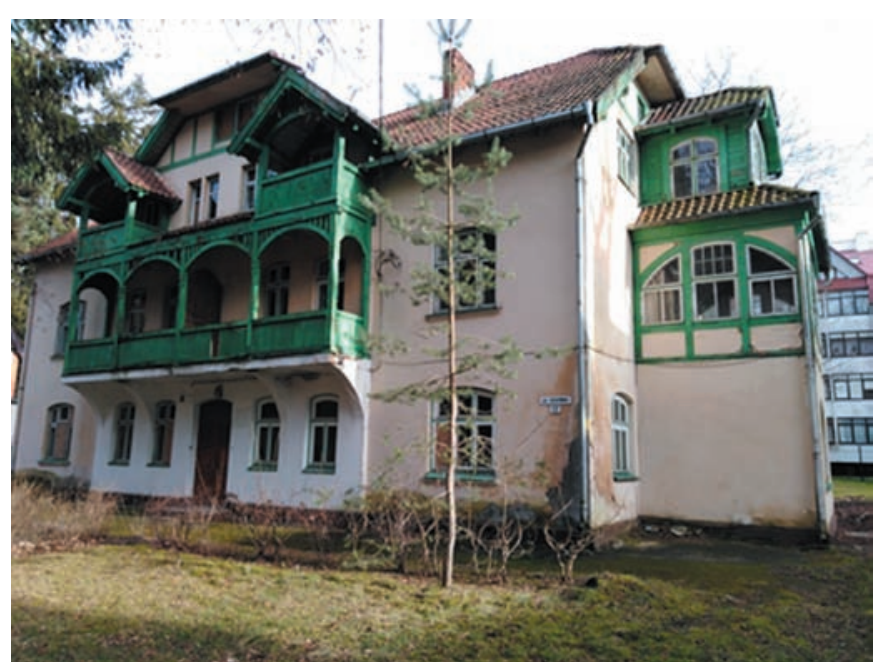

Рис. 8. Выявленный объект культурного наследия «Дом жилой» (улица Гагарина, 17). Фото В.И. Пустовгарова. 2019 год

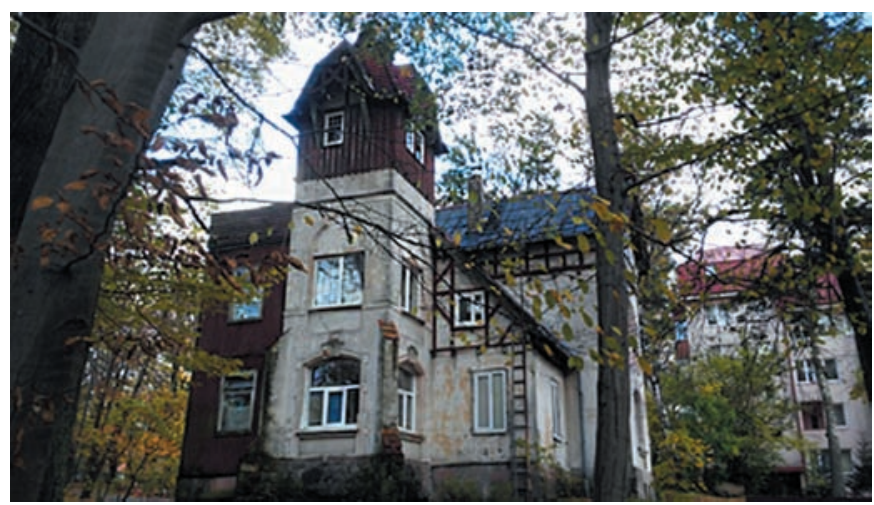

Pис. 9. Выявленный объект культурного наследия «Вилла» (улица Зелёная, 6). Фото В.И. Пустовгарова. 2019 год

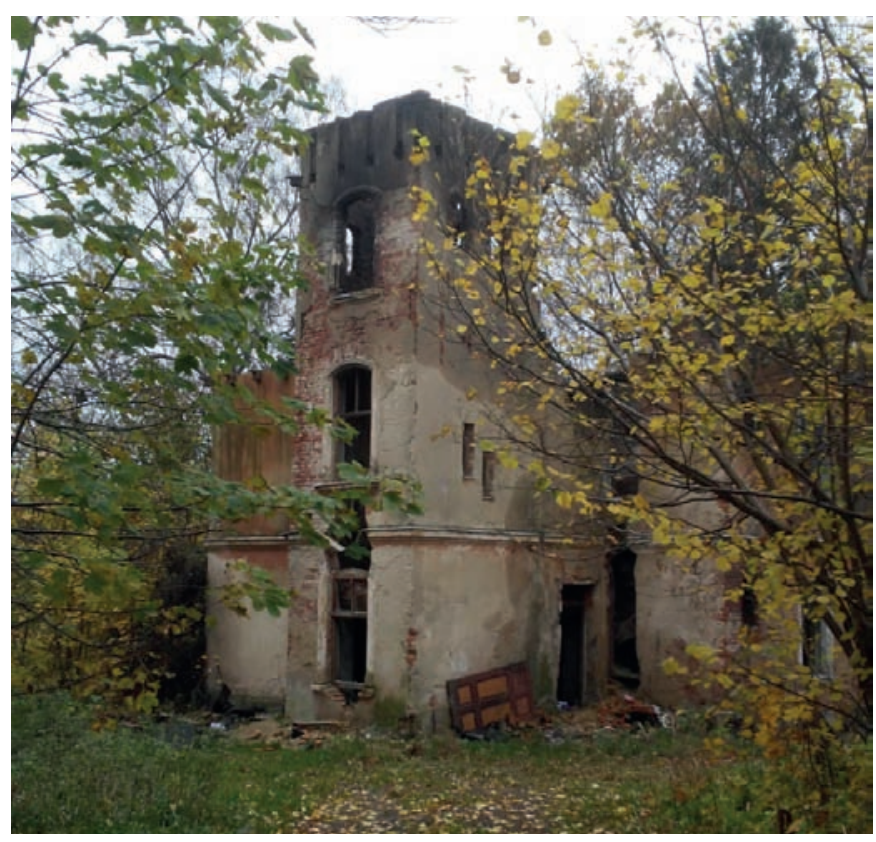

Рис. 10. Выявленный объект культурного наследия «Вилла» (Заречный проезд, 5) Фото В.И. Пустовгарова. 2019 год 
процессами и потребностями людей в среде определённого назначения. Именно поэтому эстетическое восприятие архитектурного пространства - это не пассивное отражение, то есть фиксация действительности, а результат активной духовной деятельности субъекта (отдельных людей или социальных групп), обусловленной социально-исторической ситуацией, ценностными ориентирами общества или отдельного человека, эстетическими нормами, присущими времени и культуре, а также личностными или групповыми установками, вкусами и предпочтениями [7].

В генеральном плане Приморской рекреационной функциональной зоны (2004) была определена стратегия сохранения и охраны объектов культурного наследия при его реализации, которой предусматривалось в том числе:

«- осуществление градостроительной и хозяйственной деятельности в исторических поселениях при условии обеспечения сохранности объектов культурного наследия и всех

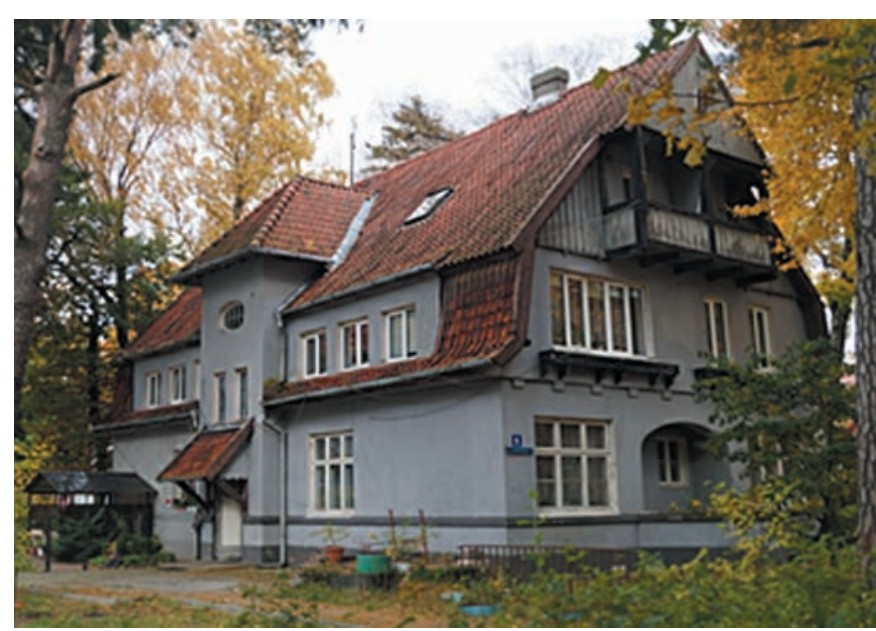

Рис. 11. Выявленный объект культурного наследия «Вилла Розенхаус» (улица Гагарина, 6). Фото В.И. Пустовгарова. 2019 год

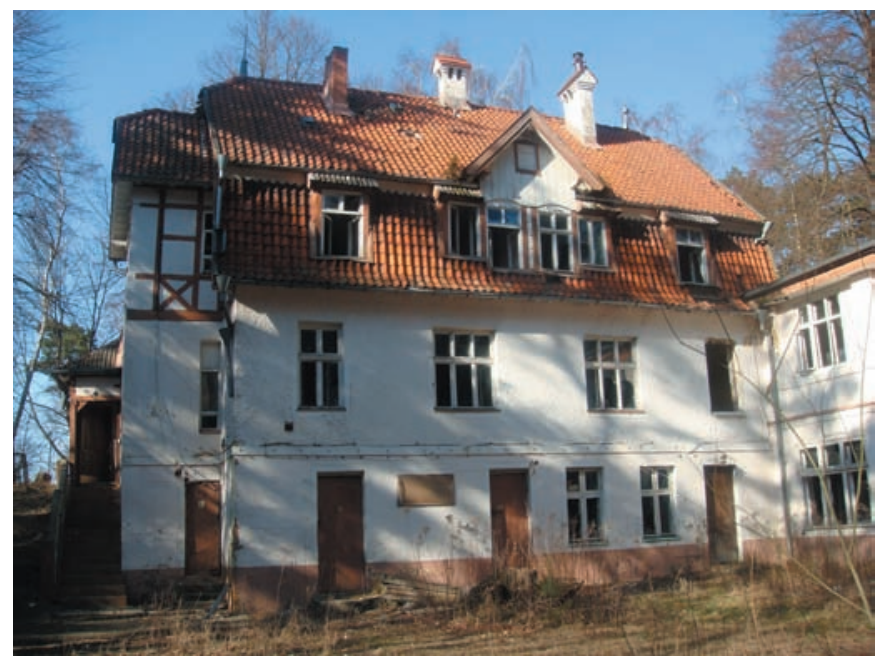

Рис. 12. Историческое здание начала ХХ века (улица Московская, 1). Фото В.И. Пустовгарова. 2019 год исторически ценных градоформирующих объектов каждого конкретного поселения;

- особое регулирование градостроительной деятельности на территориях городов-курортов;

- установление в целях обеспечения сохранности объектов культурного наследия в их исторической среде, на сопряжённой с ними территориях зон охраны культурного наследия (охранная зона, зона регулирования застройки и хозяйственной деятельности, зона охраняемого природного ландшафта) на основе научно обоснованных проектов, согласованных с региональными органами, осуществляющими контроль в области государственной охраны объектов культурного наследия региона;

- разработка программы создания новых музеев и туристских маршрутов с учётом потенциала предусмотренных генпланом к созданию рекреационных зон и комплексов».

Основная часть указанной стратегии сохранения и охраны объектов культурного наследия не была реализована, что существенно повлияло на градостроительную политику курортного города, в которой сохранение историко-культурного наследия не стало основной и обязательной задачей.

В современных экономических условиях процесс организации и управления требует новых подходов к решению задач архитектурно-градостроительного регулирования, в этой связи применительно к городу-курорту Светлогорску необходимо разработать научно-обоснованную программу сохранения и развития исторического центра, в которой одними из первоочередных задач были бы определены мероприятия по переводу выявленных объектов культурного наследия в объекты культурного наследия и внесению изменений в регламенты для зон охраны объектов культурного наследия регионального значения.

\section{Лuтература}

1. Пастернак, А.Л. Общественные центры городов античного мира средних веков и классицизма / А.Л. Пастернак. - М. : Строительство и бизнес, 2007. - 389 с.

2. Макаревич, А.П. Раушен. Курорт на Балтийском море: виды города и побережья конца XIX - первой половины XX века : альбом. - Калининград, 2019.

3. Белинцева, И.В. Архитектура морских курортов Калининградской области // И.В. Белинцева. - М.-СПб : НесторИстория, 2018. - 216 с.

4. Белинцева, И.В. Архитектура вилл Георгенсвальде (посёлок Отрадное Калининградской области) начала XX в. [Электронный ресурс] / И.В. Белинцева // Калининградские архивы. - 2014. - № 11. - С. 39-55. - Режим доступа: https:// elibrary.ru/item.asp?id=22450732 (дата обращения 20.02.2020).

5. Фёдоров, Г.М. Социально-экономическое развитие Калининградской области : учебное электронное издание. Калининград : Издательство БФУ им. И. Канта, 2015. - 156 с.

6. Щенков, А.С. Реконструкция исторических городов / А.С, Щенков - М. : Памятники исторической мысли, 2013. - 420 с. 
7. Степанов, А.В. Архитектура и психология : Учеб. пособие для вузов / А.В. Степанов, Г.И. Иванова, Н.Н. Нечаев. - М. : Стройиздат, 1993. - 295 с.

8. Бартфельд, Б.Н. Светлогорск-Раушен город шумящего моря: к 750-летию города, 1258-2008 гг. : ил. путеводитель по городу и времени / Б. Н. Бартфельд, Б. Н. Адамов. - Калининград : Рус. Европа, 2008. - 53 с.

9. Klemm, Hans-Georg. 750 Jahre Rauschen und andere samländische Orte / Hans-Georg Klemm // Unser schönes Samland. - 2008. - Frühling. - S. 35.

10. Klemm, Hans-Georg. Die Fischerei in Rauschen / HansGeorg Klemm // Unser schönes Samland. - 2015. - Sommer. - S. 47.

11. Klemm, Hans-Georg. Liebe Heimatfreunde aus Rauschen / Hans-Georg Klemm // Unser schönes Samland. - 2017. Frühling. - S. 13-16.

\section{References}

1. Pasternak A.L. Obshchestvennye tsentry gorodov antichnogo mira srednikh vekov i klassitsizma [Community Centers of Antique Cities of the Middle Age and Classicism]. Moscow, Stroitel'stvo i biznes Publ., 2007, 389 p.

2. Makarevich A. Raushen. Kurort na Baltiiskom more: vidy goroda i poberezh'ya kontsa XIX - pervoi poloviny XX veka : al'bom [Raushen. Baltic Sea resort: views of the city and the coast of the late XIX - first half of the XX century. Album]. Kaliningrad, 2019.

3. Belintseva I.V. Arkhitektura morskikh kurortov Kaliningradskoi oblast [The Architecture of the Sea Resorts of the Kaliningrad Region]. Moscow. St. Petersburg, Nestor-Istoriya Publ., 2018, 216 p.

4. Belintseva, I.V. Arkhitektura vill Georgensval'de (poselok Otradnoe Kaliningradskoi oblasti) nachala XX v. [The Architecture of the Georgenswalde villas of the Early 20th Century (Otradnoye Village, Kaliningrad Region)]. Kaliningrad archives [Kaliningrad archives], 2014, no. 11, pp. 39-55.

5. Fedorov, G.M. Sotsial'no-ekonomicheskoe razvitie Kaliningradskoi oblasti [Socio-economic Development of the Kaliningrad Region]. Kaliningrad, IKBFU Publ., 2005, 156 p.

6. Shchenkov A.S. Rekonstruktsiya istoricheskikh gorodov [Reconstruction of historical cities]. Moscow, Monuments of historical thought Publ., 2013, 420 p.

7. Stepanov A.V., Ivanova G.I., Nechaev N.N. Arkhitektura i psikhologiya [Architecture and Psychology]. Moscow, Stroyizdat Publ., 295 p.

8. Bartfeld B.N. Adamov B.N. Svetlogorsk-Raushen gorod shumyashchego morya: k 750-letiyu goroda, $1258-2008$ gg. : il. putevoditel' po gorodu i vremeni [Svetlogorsk - Raushen the city of the noisy sea: on the 750th anniversary of the city, 1258-2008 : ill. city and time guide]. Kaliningrad, Rus. Europe Publ., 53 p.

9. Klemm Hans-Georg. 750 Jahre Rauschen und andere samländische Orte. Unser schönes Samland, 2008, Frühling, S. 35.

10. Klemm Hans-Georg. Die Fischerei in Rauschen. Unser schönes Samland, 2015, Sommer, S. 47.

11. Klemm Hans-Georg. Liebe Heimatfreunde aus Rauschen // Unser schönes Samland, 2017, Frühling, ss. 13-16.

Пустовгаров Виктор Иванович (Калининград). Кандидат географических наук, советник РААСН. Почётный архитектор России. Эл.почта: viktorpustovgarov@mail.ru.

Pustovgarov Victor I. (Kaliningrad). Candidate of Geographical Sciences, Advisor of RAACS. Honorary Architect of Russia. E-mail: viktorpustovgarov@mail.ru. 